\title{
トピックス
}

\section{金属製鍊・溶解へのプラズマ の応用}

武田紘一*

プラズマを熱源あるいは反応源として用いる製鍊およ び溶解プロセスは電力多消費型であるので, この方面の 大きな発展を疑問視する向きも多い。しかしながらプラ ズマ発生装置(プラズマトーチ)は, 多様化・大型化に向 かって着実に進歩している。応用法の研究の面に打いて も基礎的なことから工業化プロセスの検討にいたるま で，多くの努力が続けられている．ここでは，はじめ に, プラズマ装置の特徵についてまとめ, ついで, 多様 化しているプラズマトーチの 2,3 の例を示し, さらに プラズマ溶解精錬と鉄鉱石のプラズマ還元について簡単 にのべ, 応用の現状の一端を紹介してみようと思う。

\section{1. プラズマの特徴}

製錬あるいは溶解の立場からみたプラズマ装置のおも な特徵としては, 次の 3 点をあげることができる。（1) 高温熱源：プラズマとはよく知られているように, 電離 したガスの集団のことである，中性のガスを電離状態に するためには多大のエネルギー ( 1000 kJ/mol)を必要 とする。裏をかえせば，プラズマは高ェンタルピーガス 体であるといらことであり, 超高温熱源として利用でき る理由でもある。エネルギー密度の高い熱源であるゆ

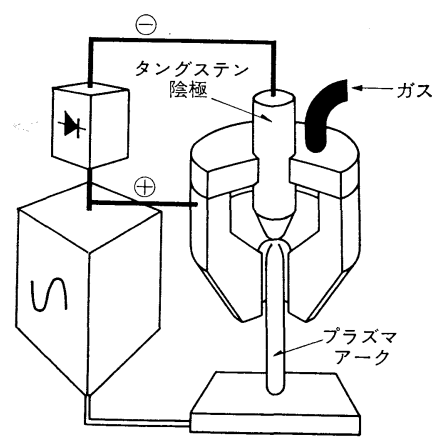

(a)

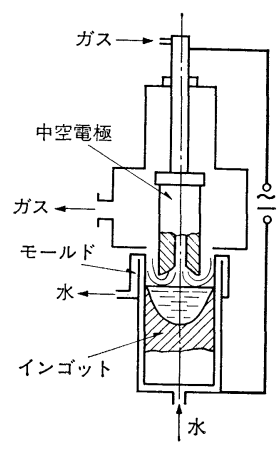

(b)
え, 小型ながら高い生産性をもつ装置の組み立てが可能 である.（2）多様かつ特殊な反応雲囲気：プラズマ装置 に拈いては利用できるガスの種類に制約が少ないため に，いろいろな反応雾囲気を作りらる，不活性なガスを

\footnotetext{
* 新日本製鉄株式会社基礎研究所研究員
} 1978 年 3 月 22 日
用いて真空場と同等な䨌囲気を作ることもできるし，燃 焼を伴わない加熱源であるので，化学反応に対するポテ ンシャルを下げることなしに高温かつ清浄な反応雾囲気 を作ることもできる，プラズマ中に存在する電離粒子， 解離原子あるいは励起原子・分子は活性状態にあると又 られ，常態では期待できない反応を進行させる可能性が ある。（3)出力が安定かつ制御容易：アーク機器に和い ては出力の変動が激しいため電源に過大な負担がかかる ことが多い. 一方プラズマ機器では出力が安定している ので,電源回路に不必要な安全度を見込まなくてもすむ. 電力機器の一般的な特徵であるがプラズマに括いても出 力の制御は容易で正確かつ迅速に行うことができる.

以上長所のみをあげたが，問題点としてはエネルギー コストが高くつくこと，プラズマガスとして多く使用さ れる $\mathrm{Ar}, \mathrm{H}_{2}$ などは, 安価なものでないこと, 部品の溶 損が激しく寿命が短いことなどがあげられるであろう。

\section{2. 改良されたプラズマトーチの例}

図 1 (a)は交流でも安定に作動できるようにされてい る交流重瞢プラズマアークトーチである(1)、交流利用の 利点は, 電源設備か簡略化されること, 直流変換に伴う 電力損がないことなどが主である．完全に交流のみで トーチを作動させると交流半周期ごとにアークの点隇が 繰返されることになるので,アークは不安定になりがち である，このトーチでは一部直流を用いて，陰極・ノズ ル間に常時アークを保持しているので, 交流を重畳して も動作は安定したものになっている.

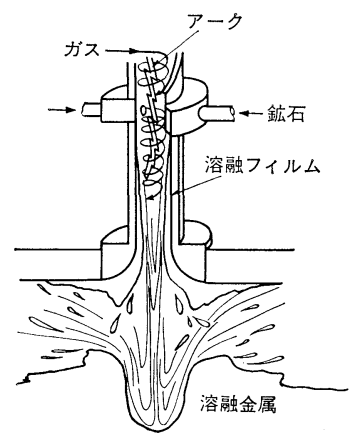

(c)
図 1

(a) 交流重畳アーク

(b) 消耗電極プラズ モトロン

(c) プラズマヒータ ー・リアクター プラズマトーチ

図 1 (b)は金属再溶解精錬用に開発されたるので, 消 耗型プラズモトロンと呼ばれている(2). アーク再溶解法 にきわめて近いながらプラズマの名が冠せられている. 再溶解すべき金属を中空円柱としこれを直接電極として 用いる．中空電極の穴を通してガスが供給され，プラズ マの䨌团気がコントロールできる，プラズマトーチとし 
て水冷部分がないため，熱効率がよい，電極が中空であ ることは，プラズマの安定化に役立っている。

図 1 (c)はプラズマヒーター・リアクターと名付けら れている.プラズマトーチを熱源装置としてだけでな く, 反応装置としての面も重要視して開発されたもので ある(3). プラズマトーチ内に送り込ま机た反応物は， トーチ内を旋回しているガス流淃き込まれ，遠心力で トーチ内壁に押しつけられてフィルム状になる.プラズ マガスにより加熱溶融されながら下へ落ちていく，内壁 面でのフィルム形成により，反応物が高温領域にさらさ れる時間が長くなり, 熱伝達が十分に抽こなわれ，反応 物間の接触混合もよくなり反応効率が高まる。

以上多様化するトーチの例を説明したが，大出力化も 進んでいる. 現在稼動しているプラズマアークトーチで は $6 \mathrm{MW}$ 出力 $(9000 \mathrm{~A}, 660 \mathrm{~V})$ のものが最大であろう ${ }^{(4)}$.

\section{3. プラズマ溶解, プラズマ製錬の研究}

プラズマの製錬拉よび溶解への応用に関しては, 1960 年頃から研究が盛んになり, 熱分解反応・酸化反応・還 元反応・塩化反応・プラズマ電解なぞ多岐にわたって検 討されて拉り，まとまった解説の類も多い(5)。ここでは， プラズマ溶解精錬と鉄鉱石の溶融還元について最近の研 究をまじえて紹介する。

\section{(1) プラズマ溶解精錬}

不活性ガス $(\mathrm{Ar})$ を用いたプラズマ溶解では，水素， 酸素等のガス成分や $\mathrm{Zn}, \mathrm{Pb}$ のよらな揮発性不純物の除 去が真空溶解と同等程度にできる。また䨌目気の圧力が あるために添加合金元素の蒸発が特さえられて歩留りが よいなどの利点も認められている。わが国ではプラズマ 加熱と誘導加熱とを組み合わせた $500 \mathrm{~kg}$ 炬が作られて 抢り，耐熱合金やステンレス鋼の製造に使われてい る(6).プラズマガスとして窒素を用いると熱平衡から予 想される值より 100 倍近い窒素が溶鋼中に溶解した例(7) もめり，高窒素鋼製造法として有効である。プラズマ溶 解では脱窒は難しいとされているが，水素プラズマを用 いることにより，低窒素鋼の溶製も可能である(8)ことが 知られている. 先に述べた図 1 (b)のような水冷モール ドをもったプラズマ再溶解法は，合金元素の歩留りがよ いこと加光，凝固が積層で進行するので，高合金鋼イ ソゴットの製造には都合がよい.

プラズマ溶解における電力原単位は炉容の大型化によ り大幅低減している。現在最大のプラズマ炉と拈もわ れる東ドイッの $30 \mathrm{t}$ 炉では，溶鋼 $1 \mathrm{t}$ あたり $500 \mathrm{kWH}$ であり†，この值は新鋭大型アーク炉での值とそう違わ ない。

$†$ 出典は文献 (4)，および “Techno Tokyo '77” (国際技術博覧会) 東ドイツ国際ライセンシング中 央局発行資料(1977)によっている。

\section{（2）鉄鉱石のプラズマ溶融還元}

図 1 (c)に示したプラズマトーチを用いた $1 \mathrm{MW}$ 出力 の装置で鉄鉱石のプラズマ溶融還元を和こなった最近の 実験 ${ }^{(9)}$ がある. 天然ガスと水素を $1 ： 2$ の割合に混合し たガスと粉鉱石をトーチ内へ吹き込んだ場合，溶鋼 $1 \mathrm{~kg}$ を得るために $2.6 \mathrm{kWH}$ の電力と約 $1 \mathrm{~m}^{3}$ の還元ガスが 必要であったと報告されている。排ガスを予備還元や予 備加熱に完全に利用しきるとして計算した理論上の必要 量は, 電力 $0.8 \mathrm{kWH,}$ 還元ガス $0.35 \mathrm{~m}^{3}$ であるので, 排ガスの利用システムを加劣れば，電力，ガスの原単位 はまだまだ下げられるものと考觉られる。

プラズマフレーム内の高温条件下では, 水素は一部電 離し一部解離して存在する. 原子状の水素の還元力は分 子状のものにくらべてはるかに大きいことが認められて いる(10)，還元プロセスの途中で鉱石中のりんが気化し て除去される現象るみつけられている(10).

このプロセスは鉄鉱石の予借処理を必要としない。 た得られる溶鉄の組成は純鉄に近いので，高炉法に打け る溶銑の脱炭処理のようなことも不要である. 現行の高 炉・転炉法との比較でい党ば, エネルギーコスト・生産 性の面でかなり劣って拈り, 近い将来プラズマ法が全面 的に高灯法に取ってかわるということはないであるう。 電力や還元剤に特殊事情のある地域ではプラズマ法が活 かされる可能性がある.

\section{文献}

(1) H.Schoumaker : 3 rd Int. Symp., Electroslag and Other Special Melting Technology, Symp. Proc., Part III, (1977), 275.

(2) B.E.Paton, K.S. Eltsov, V.I. Lakomskii, I.V.Sheiko, A.I.Pakhomov, G.E.Torkhov, A.N.Korotkov, E.I.Moshkevick and G.M. Grigorenko: Metallurgy, No 10(1974), 17 .

(3) D. R. MacRae, R. G. Gold, C. D. Thompson and W. R. Sandall : 3rd Int. Symp., Plasma Chemistry, Proc., (1977), s. 5.1.

(4) H.Fiedler, W.Lachner, G.Belka,F.Mueller, N.I.Bortnichuk and M.M.Krutjansky : 5 th Int. Symp., Electroslag and Other Special Melting Technology, Proc., (1975), 466.

（5）たとえばM. L. Thorpe : Proc. Int. Symp., Advances in Extractive Metallurgy and Refining, (1972) , 275.

（6）野田 浩, 浅田千秋, 江口 勇, 足立敏夫, 林 清英: 電気製鋼, 41 (1970), 13 .

（7）武田紘一，中村 泰：鉄と鋼，63(1977)，227.

（8）金子恭二郎 佐野信雄, 松下幸雄：鉄と鋼, 62 (1976), 43.

(9) R.G.Gold, W.R.Sandall, R.G.Cheplick and D. R. MacRae : Ironmaking and Steelmaking, 4 (1977), 10.

（10）中村 泰, 井藤三千寿, 石川英毅：鉄と鋼，63 (1977) , S 12 . 